DOI https://doi.org/10.30525/978-9934-26-073-5-1-76

\title{
ЗАПОЗИЧЕННЯ З ІНШИХ МОВ ЯК СПОСІБ ТВОРЕННЯ СУЧАСНИХ АНГЛОМОВНИХ СОФТОНІМІВ
}

\author{
Юшак В. М. \\ кандидат філологічних наук, \\ стариий викладач кафедри англійської філології \\ Волинського національного університету імені Лесі Українки, \\ м. Луиьк, Украӥна
}

Сучасній англійській мові притаманні постійні зміни ії словникового складу. Завдяки досягненням у галузі інформаційних технологій лексичний фонд англійської мови поповнюється новими лексичними одиницями. У мовленні сучасні користувачі персональних комп'ютерів використовують найрізноманітніші лексеми на позначення програмного забезпечення, комплектувальних, пристроїв, операцій і дій, пов'язаних із комп'ютерною обробкою.

У сучасних лінгвістичних розвідках аналізують особливості інтернеткомунікації (С. Грайфанштерн [7], Д. Кристал [5; 6], різні аспекти комп'ютерного лексикону (М. Ю. Карпенко [2], Н. В. Лазебна [3], О. С. Чирвоний [4]).

Ринок програмного забезпечення постійно розширюється внаслідок появи нових розробок i, відповідно, - їхніх назв. Уважаємо, що англомовні назви комп'ютерних програм (софтоніми) уходять до складу ономастичного простору сучасної англійської мови й утворюють окрему ономастичну групу класу прагмонімів.

Аналіз фактичного матеріалу засвідчив, що серед засобів номінації комп'ютерних програм розробники застосовують досить ефективний спосіб - запозичення слів з інших мов. Такий спосіб непоширений для поповнення словникового складу англійської мови. Нові лексичні одиниці утворюються через використання внутрішніх мовних ресурсів. Ю. А. Зацний зазначає: «існує тенденція зниження питомої ваги запозичень серед неологізмів англійської мови: надходження з інших мов в останне десятиліття становлять приблизно 2,0 \%» [1, с. 165].

Як назви запозичення створюють ефект загадковості, новизни, а незвична комбінація звуків у звучанні лексичної одиниці викликає інтерес у користувача персонального комп'ютера. Запозичення на позначення програмних ресурсів ужиті і в прямому, і в непрямому значеннях. 
У наступних назвах іноземні слова (нім. Kinder, грец. logo (logos), японс. midori, 3 івриту mellel) використані в прямому значенні (відповідно діти, слово, зелений колір, текст). За умови оформлення цих значень англійською мовою, оніми не виконували б репрезентативну, розпізнавальну та функцію привертання уваги, реалізація яких обов'язкова для успіху номінації. У назвах системних та прикладних програм запозичення несуть додаткове семантичне навантаження: програма для блокування небезпечних для дітей сайтів KinderGate, мова програмування Logo, веб-браузер Midori, текстовий процесор Mellel.

Наступна група назв, утворених на основі запозичень 3 інших мов, побудовані на метафоричому перенесенні. Назва операційної системи Ubuntu - запозичення з південноафриканської мови, яке перекладається із цієї мови як «людяність». Автори операційної системи так пояснюють походження назви: «Ubuntu is an ancient African word meaning 'humanity to others'. It also means 'I am what I am because of who we all are'. The Ubuntu operating system brings the spirit of Ubuntu to the world of computers» [8]. Враховуючи принципи утворення концептуальних метафор, вважаємо, що назва операційної системи Ubuntu - приклад концептуальної метафори SOFTWARE IS A HUMAN BEING, оскільки людяність як риса $є$ характеристикою лише людини.

Назва текстового редактора Diakonos - запозичення з грецької мови та має значення «служитель». Хоча онім не містить інформації про функціональні можливості програми, приховане непряме значення створює сильніший рекламний ефект - «текстовий редактор є помічником користувача комп'ютерів».

Основне семантичне навантаження в назві веб-браузера Avant Browser виконує прикметник avant, який у перекладі з французької мови означає «передній, передуючий». Запозичений з іншої мови атрибутивний компонент avant додає ще одне непряме значення - «веб-браузер за своїми функціональними можливостями випереджає інші системи цього класу». Запозичення avant у структурі софтоніма містить частковооцінне значення і виділяє таку якість програмних ресурсів, як новизна.

Наступний софтонім теж емоційно-оцінний. Назва архіватора Наozip у перекладі 3 китайської означає «good or well». Запозичена лексична одиниця як номінація комп'ютерної програми виконує функцію переконання у відмінній роботі програми та доброму результаті. Такий софтонім налаштовує користувача на позитивні емоції.

Запозичення 3 німецької, грецької, японської, івриту, південноафриканської, французької, китайської мов у функції назв комп'ютерних 
програм викликають зацікавленість користувачів програмного забезпечення у зв'язку зі своєю екзотичністю. Більшість іншомовних лексем, які у мові-джерелі мають пряме значення, унаслідок міжмовної транспозиції отримує метафоричний смисл.

Результати дослідження англомовних софтонімів-запозичень демонструють, що розробники програмного забезпечення використовують внутрішні лексичні ресурси англійської мови для номінації програмних продуктів, що підтверджує основну тенденцію словотворчого процесу сучасної англійської мови до зменшення надходження лексичних одиниць з інших мов.

\section{Література:}

1. Зацний Ю. А. Сучасний англомовний світ і збагачення словникового складу. Львів: ПАІС, 2007. 228 с.

2. Карпенко М. Ю. Онімний простір Інтернету. Монографія. Одеса: КП ОГТ, 2017. 195 с.

3. Лазебна Н. В. Структурно-семантичні і функціональні особливості комп'ютерної термінологічної лексики 3 образним компонентом у сучасній англійській мові : автореф. дис. ... канд. філол. наук : 10.02.04. Донецьк : ДонНУ, 2013. 20 с.

4. Чирвоний О. С. Комп’ютерний лексикон сучасної англійської мови: структурний, семантичний, функціональний аспекти : автореф. дис.... канд. філол. наук. Одеса : Одес. нац. ун-т ім. I. І. Мечникова, 2010. 17 c

5. Crystal D. Internet Linguistics: A Student Guide. New York: Routledge, 2011. 179 p.

6. Crystal D. Language and the Internet. Cambridge: Cambridge University Press, 2004. 272 p.

7. Greiffenstern S. The Influence of Computers, the Internet and Computer-Mediated Communication on Everyday English. Berlin: Logos Verlag Berlin GmbH, 2010. 223 p.

8. The story of Ubuntu. https://ubuntu.com/about 